\title{
Spieëltjie, spieëltjie ... ?
}

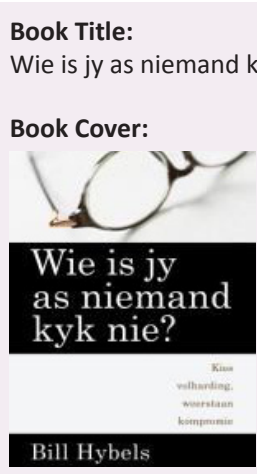

Author:

B. Hybels

ISBN:

978-4316-0003-8

Publisher:

Christelike Uitgewers-

maatskappy, 2012, R89.95

*Book price at time of review

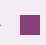

Review title:

Spieëltjie, spieëltjie ... ?

Reviewer:

Raymond Potgieter ${ }^{1}$

\section{Affiliation:}

${ }^{1}$ Faculty of Theology,

North-West University,

Potchefstroom Campus,

South Africa

Email:

ray@csmdist.com

Postal address:

PO Box 19491, Noordbrug

2522 , South Africa

How to cite this book review: Potgieter, R., 2013,

'Spieëltjie, spieëltjie ... ?',

In die Skriflig/In Luce Verbi

47(1), Art. \#664, 1 page.

http://dx.doi.org/10.4102/

ids.v47i1.664

\section{Copyright:}

C 2013. The Authors.

Licensee: AOSIS

OpenJournals. This work

is licensed under the

Creative Commons

Attribution License.

\section{Read online:}

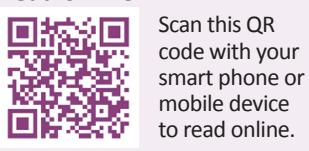

Daar het reeds verskeie publikasies uit die pen van Bill Hybels, senior pastoor van Willow Creek Community Church in die VSA, gekom. Die eerste uitgawe van hierdie boek is al meer as 20 jaar gelede uitgegee en is nou ook in Afrikaans vertaal. In die lig van die stroom nuwe publikasies en die oormaat kennis en verandering waarmee 'n mens daagliks te doen kry, is so 'n lang rakleeftyd iets besonders. Die onmiddellike gevolgtrekking is dat hierdie 'n boek is wat lesers aangryp en waarvan die inhoud nog steeds toepaslik is.

Hybels se bekommernis is oor die stand van sake in die samelewing (lees hoofsaaklik VSA) en hy stel dit dat Christene 'n positiewe verskil tot eer van God kan maak. Hy gaan van die veronderstelling uit dat mense na die goeie hunker, maar in sondige leefpatrone vasgevang bly. Christene word aangemoedig om nie moedeloos te word en op te gee nie, maar om eerder hulle geloof uit te leef om sodoende 'n verskil te maak wat verandering tot gevolg kan hê. Om hierin te slaag, moet die karakter van God uitgedra word deur 'n goddelike leefwyse. Die waarde van die boek lê juis hierin dat dit Christene uitdaag om hulle getuienis eerlik in die openbaar sowel as in die binnekamer te evalueer. Dit is eintlik laasgenoemde wat vir Hybels as die bepalende maatstaf dien. Hy meen dat getuienis persoonlik en met absolute eerlikheid geassesseer behoort te word, omdat dit uiteindelik net die individu en sy of haar versoekings is wat geëvalueer word met niemand anders om die woede of trane van berou te keer of wie beïndruk moet word nie. Dit is net die individu en God.

Hy pleit vir 'n getuienis wat konsekwent die karakter van God uitbeeld. Hybels gee insigte vir agt basiese karaktereienskappe, waaronder moed, dissipline, visie, volharding en liefde. Laasgenoemde onderskei hy as tere, streng, opofferende en radikale liefde en herlei dit terug na die karaktereienskappe. Hierdie onderverdeling van liefde neem amper die helfte van die boek in beslag. Bill Milliken, bekende kinderbedienaar, het aanvanklik die idee in sy boek 'Tough love' (1968) gepromoveer. Die verdeling van liefde in onderafdelings kan egter die indruk gee dat 'n persoon soms na die een of ander uiterste neig in plaas daarvan om die liefdesbeeld in die geheel uit te straal.

Hybels rugsteun sy skrywe met gereelde relevante of persoonlike verwysings na sy eie swakhede. Dit dra by om die boek se boodskap te verpersoonlik. Gereelde Skrifverwysings verdiep die boodskap. Sommige van die voorbeelde is in die eerste wêreld (bl. 11, 61) gekontekstualiseer, maar dit domineer nie die oorhoofse boodskap nie. Soms kry 'n mens die indruk dat die boek so letterlik vertaal is dat dit die vloei van die gesprek in die teks tot 'n mate benadeel.

Hierdie is beslis 'n vakansieboek - 'n boek wat ouers saam met hulle kinders (bv. hoofstuk 10) kan lees en saam daaroor 'n gesprek kan voer. Dit is egter ook gebruikersvriendelik vir klein of groot groepe in die gemeentebediening. Hierdie is ook ' $n$ boek vir persoonlike bemagtiging - in die binnekamer met God alleen. Daar het die leser die geleentheid het om met diep nadenke eerlike selfondersoek te doen, swakhede te bely en om te sê 'Here help my om 'n verskil in hierdie sondige wêreld te maak.' Hybels se boodskap is: 'As jy kan asemhaal, kan jy, as Christen, deur woord en daad 'n samelewingsverskil maak.' 